\title{
Structural characterization and composition of Y-rich hainite from Sakharjok nepheline syenite pegmatite (Kola Peninsula, Russia)
}

\author{
L. Lyalina ${ }^{1}$ - A. Zolotarev $\mathrm{Jr}^{2}$ - E. Selivanova ${ }^{1}$ - Ye. Savchenko ${ }^{1}$ - D. Zozulya ${ }^{1}$. \\ S. Krivovichev ${ }^{2} \cdot$ Yu. Mikhailova ${ }^{1}$
}

Received: 8 December 2014 / Accepted: 18 March 2015

(C) Springer-Verlag Wien 2015

\begin{abstract}
Y-rich hainite occurs in nepheline syenite pegmatite of the Sakharjok massif (Kola Peninsula, Russia). It forms euhedral prismatic crystals up to $2 \mathrm{~mm}$ in length as well as rims around an unidentified mineral phase (silicate of $\mathrm{Ca}, \mathrm{Y}$, $\mathrm{Zr}$ and Ti). The mineral is triclinic, space group $P-1, a$ 9.6054(10), b 5.6928(6), c 7.3344(7) $\AA, \alpha$ 89.903(2), $\beta$ 101.082(2), $\gamma$ 100.830(2) $, V 386.32(7) \AA^{3}, Z=1$. The calculated density is $3.39 \mathrm{~g} / \mathrm{cm}^{3}$. Chemical composition of Sakharjok hainite is different from the previously published data by much higher $\mathrm{Y}$ and $\mathrm{Nb}$ contents up to 0.72 and 0.20 atoms per formula unit, respectively, by the two- to five-fold depletion in the LREEs and by the strong enrichment of the HREEs. From the single-crystal X-ray diffraction data, there is a significant amount of $\mathrm{Y}$ in the M1 site associated with the absence of $\mathrm{Zr}$ in it. $\mathrm{Nb}$ and $\mathrm{Zr}$ are concentrated in the M5 site substituting Ti. Combination of single-crystal X-ray diffraction data and electron microprobe data give the empirical formula $\left(\mathrm{Ca}_{1.04} \mathrm{Y}_{0.63} \mathrm{REE}_{0.24} \mathrm{Mn}_{0.02}\right)_{\sum 1.93}\left(\mathrm{Na}_{0.92} \mathrm{Ca}_{0.77}\right)_{\sum 1.69} \mathrm{Ca}_{2.00}$ $\left(\mathrm{Na}_{0.65} \mathrm{Ca}_{0.10}\right)_{\sum 0.75}\left(\mathrm{Ti}_{0.60} \mathrm{Zr}_{0.21} \mathrm{Nb}_{0.15} \mathrm{Fe}_{0.03}\right)_{\Sigma 0.99}$ $\left(\left(\mathrm{Si}_{4.00} \mathrm{Al}_{0.02}\right)_{\sum 4.02} \mathrm{O}_{14}\right)\left(\mathrm{F}_{2.61} \mathrm{O}_{1.39}\right)_{\sum 4.00}$.
\end{abstract}

Editorial handling: L. Bindi

L. Lyalina

lialina@geoksc.apatity.ru

1 Geological Institute, Kola Science Centre, Russian Academy of Sciences, Apatity, Russia

2 Department of Crystallography, Saint-Petersburg State University, St-Petersburg, Russia

\section{Introduction}

Hainite was originally described by Blumrich (1893) in phonolites and tinguaites from Hradište, Northern Bohemia, and was named after the place of its discovery, the Hoher Hain Mountain. A comprehensive investigation of the type material was reported by Johan and Čech (1989). Crystal structure of hainite from type locality was solved by Giester et al. (2005). Another find of hainite was reported from phonolites of the PoÇos de Caldas massif, Minas Gerais, Brazil (Guimarães 1948). Mineral from this occurrence was named «giannettite», as authors were not aware about the previous reports of the same mineral by Blumrich (1893). Later the mineral from PoÇos de Caldas was reinvestigated and was properly identified as hainite (Atencio et al. 1999). Hainite had also been reported from pegmatites related to nepheline syenites of the Langesund Fjord, Norway (Christiansen et al. 2003) and pulaskites of the Ilímaussaq alkaline complex, Greenland (Rønsbo et al. 2014). Hainite is of late- and post-magmatic origin, and occurs in pegmatites and volcanic vugs.

Hainite belongs to the rosenbuschite mineral group together with rosenbuschite, götzenite, seidozerite, kochite and grenmarite. In general, the rosenbuschite-group minerals are titanosilicates and zirconosilicates with layered structures (Christiansen et al. 2003; Sokolova 2006; Sokolova and Camara 2013; and references therein). They normally occur in alkaline rocks and related Si-undersaturated rocks. The group shows a wide compositional variability hosting a large number of elements. Besides $\mathrm{Si}$ the main cations are $\mathrm{Na}, \mathrm{Ca}$, $\mathrm{Y}, \mathrm{Mn}, \mathrm{Fe}, \mathrm{Ti}, \mathrm{Mg}, \mathrm{Zr}, \mathrm{Nb}$, and $R E E$, which occur in various concentrations. Christiansen et al. (2003) carried out a systematic study on a series of rosenbuschite-group minerals in order to describe their crystal chemistry in more details. Hainite, $\mathrm{Na}_{2} \mathrm{Ca}_{4}(\mathrm{Y}, \mathrm{REE}) \mathrm{Ti}\left(\mathrm{Si}_{2} \mathrm{O}_{7}\right)_{2} \mathrm{OF}_{3}$, and götzenite,

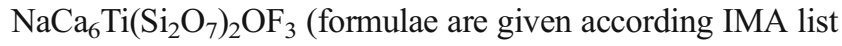


of minerals), are closely related in their composition and crystal structure. Hainite is different from the götzenite in that it contains more $\mathrm{Na}$ and $\mathrm{Y}$, which occupy separate sites in the crystal structure (Christiansen et al. 2003). It is noteworthy that hainite samples from the all previously known occurrences display relatively wide chemical and structural variations. For example, only $\mathrm{Ce}$ and $\mathrm{La}$ have been reported for hainite from the type locality Hradište (suggesting that $\mathrm{Y}$ and other REEs are negligible), and its space group was determined as $P-1$. The same group was found for triclinic hainite from Langesund with disordered cation distribution in the M2 site. The mineral from Minas Gerais is characterized by the ordered $\mathrm{Ca}$ and $\mathrm{Na}$ distribution, which results in the lower symmetry and the space group $P 1$ (Atencio et al. 1999). The $\mathrm{Y}$ and REE contents for Minas Gerais hainite are relatively low (0.01-0.07 and 0.08-0.24 apfu (atoms per formula unit)). Hainite from Langesund and from Ilímaussaq have more elevated $\mathrm{Y}$ and $R E E$ contents $(0.3$ and $0.25,0.22$ and 0.32 apfu, respectively). Therefore, the proper identification of hainite requires both detailed chemical and structural study.

Herein we provide the comprehensive mineral investigation (X-ray powder diffraction (XRPD), single-crystal X-ray diffraction (SCXRD), electron microprobe analysis (EMPA)) of the Y-rich hainite from the Sakharjok massif, Kola Peninsula, Russia, which is the first report of the mineral for this particular mineral locality.

\section{Occurrence}

Sakharjok massif is located in the central part of Kola Peninsula, NW Russia. The massif represents the fissuretype alkaline intrusion and extends up to $8 \mathrm{~km}$ with the maximal width of $1.5-2 \mathrm{~km}$ in its northern part. The massif is composed mainly of alkaline syenites and nepheline syenites and genetically related pegmatoid schlierens and veins (Batieva and Bel'kov 1984; Zozulya et al. 2012). Large essexite outcrops up to $80 \times 200 \mathrm{~m}$ in area occur within nepheline syenite. Essexite represents the phlogopite-pyroxeneplagioclase rock with minor nepheline and amphibole. Syenite intrudes essexite resulting in the formation of numerous fractures subsequently filled by a pegmatitic material. The pegmatite body outcrops up to $30 \mathrm{~m}^{2}$ in area and is remarkable for the abundant meliphanite $\left(\mathrm{Ca}_{4}(\mathrm{Na}, \mathrm{Ca})_{4} \mathrm{Be}_{4} \mathrm{AlSi}_{7} \mathrm{O}_{24}(\mathrm{~F}\right.$, $\mathrm{O})_{4}$ ) mineralization. Recent studies demonstrated that the locality has more Be-bearing minerals such as leucophanite, behoite, and gadolinite (Lyalina et al. 2010). The REE and chalcophile mineralization is of less extent and is represented by the britholite group minerals, REE bearing apatite, mimetite, nickeline, molybdenite and unidentified $\mathrm{Pb}$ phases (Lyalina et al. 2010, 2014). The pegmatite exhibits a complex internal structure and consists of two rock units differing by both texture and mineral assemblage. The first rock unit has a

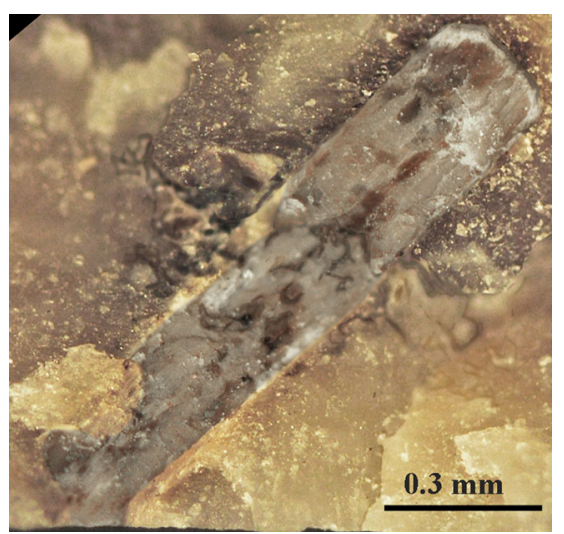

Fig. 1 Prismatic crystal of hainite in aggregate of zeolites in the Sakharjok pegmatite, Kola Peninsula
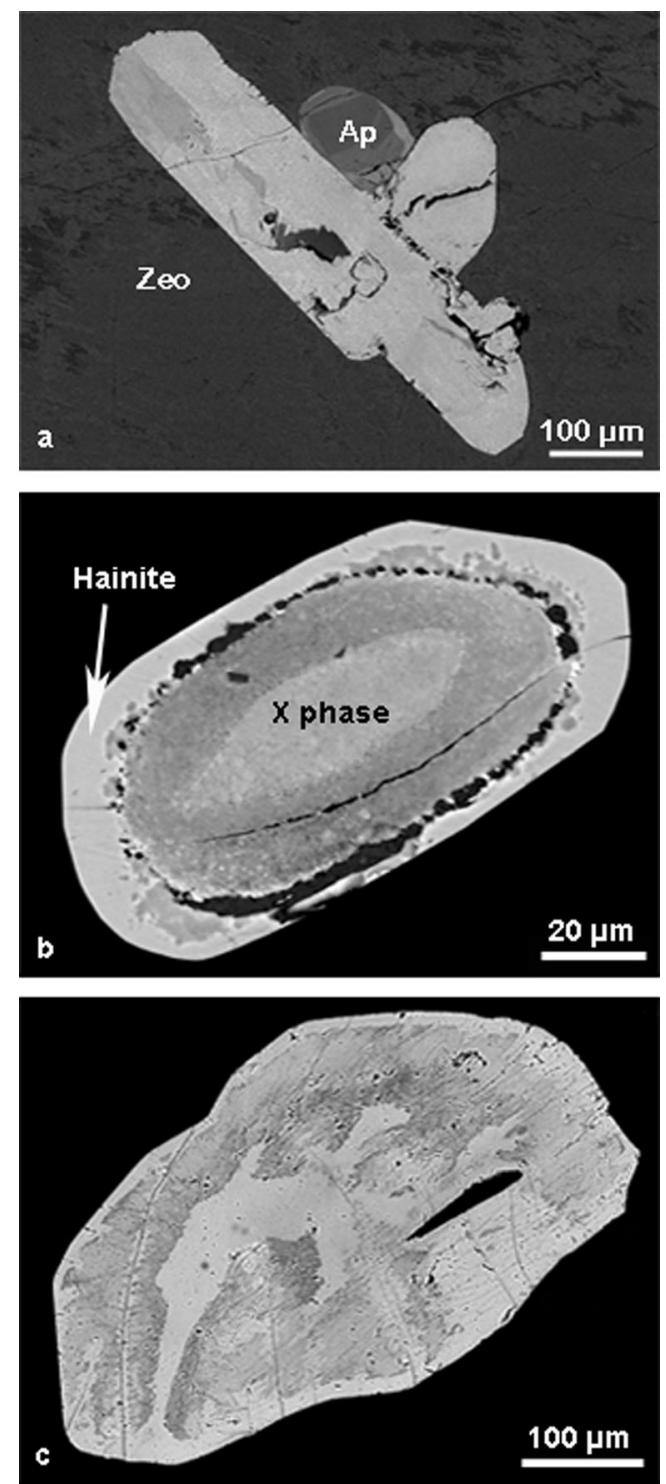

Fig. 2 Back-scattered electron (BSE) images of the hainite from the Sakharjok pegmatite. a Intergrowth of two prismatic hainite crystals and apatite (Ap) in zeolite matrix (Zeo). b Hainite rim around phase X. c Anhedral crystal of hainite with altered zones (more dark in BSE) 
Table 1 Representative compositions of hainite from the Saharjok pegmatite (Kola Peninsula, Russia).

\begin{tabular}{|c|c|c|c|c|c|c|}
\hline \multirow[t]{2}{*}{ Sample } & \multirow{2}{*}{$\begin{array}{l}1 \\
N=1\end{array}$} & \multirow{2}{*}{$\begin{array}{l}2 \\
N=1\end{array}$} & \multirow{2}{*}{$\begin{array}{l}3 \\
N=1\end{array}$} & \multicolumn{2}{|l|}{4} & \multirow{2}{*}{$\begin{array}{l}5 \\
N=1\end{array}$} \\
\hline & & & & $N=5$ & $\min -\max$ & \\
\hline $\mathrm{SiO}_{2}$ & 30.20 & 30.97 & 31.00 & 30.74 & $30.17-31.36$ & 31.38 \\
\hline $\mathrm{Al}_{2} \mathrm{O}_{3}$ & 0.15 & 0.37 & 0.39 & 0.16 & $0.12-0.18$ & 0.40 \\
\hline $\mathrm{TiO}_{2}$ & 6.55 & 6.95 & 8.64 & 6.09 & $5.66-6.71$ & 7.72 \\
\hline $\mathrm{ZrO}_{2}$ & 2.52 & 1.88 & 0.94 & 3.25 & $1.09-4.77$ & 1.46 \\
\hline $\mathrm{Nb}_{2} \mathrm{O}_{5}$ & 3.23 & 2.81 & 0.58 & 2.56 & $2.10-3.31$ & 1.58 \\
\hline $\mathrm{MnO}$ & 0.27 & 0.22 & 0.15 & 0.20 & $0.16-0.23$ & 0.18 \\
\hline $\mathrm{FeO}$ & 0.17 & 0.29 & 0.28 & 0.27 & $0.18-0.36$ & 0.12 \\
\hline $\mathrm{CaO}$ & 28.88 & 29.30 & 29.87 & 28.08 & $27.91-28.21$ & 28.75 \\
\hline $\mathrm{Na}_{2} \mathrm{O}$ & 6.84 & 7.33 & 7.14 & 6.24 & $5.88-6.73$ & 6.88 \\
\hline $\mathrm{Y}_{2} \mathrm{O}_{3}$ & 9.13 & 9.83 & 10.50 & 9.08 & $8.63-9.51$ & 10.05 \\
\hline $\mathrm{La}_{2} \mathrm{O}_{3}$ & 0.25 & 0.11 & 0.12 & 0.00 & 0.00 & 0.06 \\
\hline $\mathrm{Ce}_{2} \mathrm{O}_{3}$ & 0.36 & 0.14 & 0.20 & 0.22 & $0.18-0.27$ & 0.00 \\
\hline $\mathrm{Nd}_{2} \mathrm{O}_{3}$ & 0.14 & 0.00 & 0.00 & 0.03 & $0.00-0.13$ & 0.00 \\
\hline $\mathrm{Gd}_{2} \mathrm{O}_{3}$ & 0.10 & 0.18 & 0.12 & 0.14 & $0.13-0.16$ & 0.17 \\
\hline $\mathrm{Tb}_{2} \mathrm{O}_{3}$ & 0.00 & 0.15 & 0.11 & 0.00 & 0.00 & 0.00 \\
\hline $\mathrm{Dy}_{2} \mathrm{O}_{3}$ & 0.33 & 0.45 & 0.55 & 0.44 & $0.42-0.49$ & 0.35 \\
\hline $\mathrm{Ho}_{2} \mathrm{O}_{3}$ & 0.14 & 0.19 & 0.19 & 0.00 & 0.00 & 0.00 \\
\hline $\mathrm{Er}_{2} \mathrm{O}_{3}$ & 1.08 & 0.89 & 0.87 & 1.12 & $1.05-1.18$ & 0.82 \\
\hline $\mathrm{Tm}_{2} \mathrm{O}_{3}$ & 0.15 & 0.24 & 0.30 & 0.32 & $0.25-0.37$ & 0.37 \\
\hline $\mathrm{Yb}_{2} \mathrm{O}_{3}$ & 2.47 & 2.47 & 2.36 & 2.93 & $2.81-3.06$ & 2.40 \\
\hline $\mathrm{Lu}_{2} \mathrm{O}_{3}$ & 0.44 & 0.34 & 0.30 & 0.50 & $0.48-0.52$ & 0.45 \\
\hline $\mathrm{F}$ & n.d. & 6.24 & 6.80 & 6.26 & $6.17-6.35$ & 6.68 \\
\hline $\mathrm{O}=\mathrm{F} 2$ & 0.00 & 2.63 & 2.86 & 2.64 & $2.60-2.67$ & 2.81 \\
\hline Total & 93.40 & 98.99 & 98.81 & 96.00 & & 97.01 \\
\hline \multicolumn{7}{|c|}{ apf $u$ on the basis $\mathrm{Si}=4\left(\mathrm{M}_{2}{ }_{2} \mathrm{M} 2{ }_{2} \mathrm{M}{ }_{2} \mathrm{M} 4 \mathrm{M} 5\left[\mathrm{Si}_{2} \mathrm{O}_{7}\right]_{2} \mathrm{X}_{4}\right)$} \\
\hline $\mathrm{Si}$ & 4.00 & 4.00 & 4.00 & 4.00 & 4.00 & 4.00 \\
\hline $\mathrm{Al}$ & 0.02 & 0.06 & 0.06 & 0.02 & $0.02-0.03$ & 0.06 \\
\hline $\mathrm{Ti}$ & 0.65 & 0.67 & 0.84 & 0.60 & $0.55-0.67$ & 0.74 \\
\hline $\mathrm{Zr}$ & 0.16 & 0.12 & 0.06 & 0.21 & $0.07-0.30$ & 0.09 \\
\hline $\mathrm{Nb}$ & 0.19 & 0.16 & 0.03 & 0.15 & $0.12-0.20$ & 0.09 \\
\hline $\mathrm{Mn}$ & 0.03 & 0.02 & 0.02 & 0.02 & $0.02-0.03$ & 0.02 \\
\hline $\mathrm{Fe}$ & 0.02 & 0.03 & 0.03 & 0.03 & $0.02-0.04$ & 0.01 \\
\hline $\mathrm{Ca}$ & 4.10 & 4.05 & 4.13 & 3.91 & $3.86-4.13$ & 3.93 \\
\hline $\mathrm{Na}$ & 1.76 & 1.83 & 1.79 & 1.57 & $1.48-1.73$ & 1.70 \\
\hline $\mathrm{Y}$ & 0.64 & 0.68 & 0.72 & 0.63 & $0.59-0.65$ & 0.68 \\
\hline $\mathrm{La}$ & 0.01 & 0.01 & 0.01 & 0.00 & 0.00 & 0.00 \\
\hline $\mathrm{Ce}$ & 0.02 & 0.01 & 0.01 & 0.01 & 0.01 & 0.00 \\
\hline $\mathrm{Nd}$ & 0.01 & 0.00 & 0.00 & 0.00 & $0.00-0.01$ & 0.00 \\
\hline $\mathrm{Gd}$ & 0.00 & 0.01 & 0.01 & 0.01 & 0.01 & 0.01 \\
\hline $\mathrm{Tb}$ & 0.00 & 0.01 & 0.00 & 0.00 & 0.00 & 0.00 \\
\hline Dy & 0.01 & 0.02 & 0.02 & 0.02 & 0.02 & 0.01 \\
\hline Но & 0.01 & 0.01 & 0.01 & 0.00 & 0.00 & 0.00 \\
\hline $\mathrm{Er}$ & 0.04 & 0.04 & 0.04 & 0.05 & $0.04-0.05$ & 0.03 \\
\hline $\mathrm{Tm}$ & 0.01 & 0.01 & 0.01 & 0.01 & $0.01-0.02$ & 0.01 \\
\hline $\mathrm{Yb}$ & 0.10 & 0.10 & 0.09 & 0.12 & $0.11-0.12$ & 0.09 \\
\hline $\mathrm{Lu}$ & 0.02 & 0.01 & 0.01 & 0.02 & 0.02 & 0.02 \\
\hline
\end{tabular}

Table 1 (continued)

\begin{tabular}{clllllll}
\hline Sample & 1 & 2 & 3 & 4 & & \multirow{2}{*}{5} \\
\cline { 5 - 6 } & $N=1$ & $N=1$ & $N=1$ & $N=5$ & $\min -\max$ & \multirow{2}{*}{$N=1$} \\
\hline F & 0.00 & 2.55 & 2.77 & 2.61 & $2.59-2.63$ & 2.69 \\
Sum_cations M & 7.78 & 7.81 & 7.84 & 7.36 & & 7.43 \\
\hline
\end{tabular}

1, 5 - anhedral crystals; 2, 3 - euhedral zonal crystal (2 - brighter in BSE zone (total includes $\mathrm{SrO}=0.25$ wt. $\%, \mathrm{~K}_{2} \mathrm{O}=0.02$ wt. $\%$ ), 3 - darker in $\mathrm{BSE}$ zone $\left(\mathrm{K}_{2} \mathrm{O}=0.03\right.$ wt. $\%, \mathrm{Pr}_{2} \mathrm{O}_{3}=0.23$ wt. $\left.\left.\%\right)\right) ; 4$ - average and range for 5 analyses from hainite rim (total average includes $\mathrm{MgO}=0.01 \mathrm{wt} \%$ (range $\mathrm{MgO}=0-0.07))$

taxitic structure and is characterized by the development of aggregates of leucocratic and melanocratic minerals. The main rock-forming mineral of the melanocratic aggregates is mica (the phlogopite-annite series) forming variably oriented laths of 1-2 cm (rarely up to $4 \mathrm{~cm}$ ) in size. The interstices between mica grains are filled with pyroxene (aegirine-augite), unhedral fluorite and minor leucocratic minerals (analcime, thomsonite, albite, nepheline). The leucocratic aggregate has a fine- or medium-grained structure, has white-pink color and consists of the above mentioned minerals. The minor minerals of the leucocratic aggregates are mica, pyroxene and fluorite. The euhedral tabular crystals of meliphanite are up to $3-4 \mathrm{~cm}$ in size and occur in both melanocratic and leucocratic aggregates. The second rock unit of the pegmatite has a zonal structure and is typical for the pegmatite bulges. Batieva and Bel'kov (1984) distinguish three zones within it: a wall zone composed of a coarse-grained aggregate of analcime, nepheline and its alteration products; an intermediate zone with blocky nepheline and analcime; a core zone consisting of albite with rare-metal mineralization.

The characteristic feature of the pegmatite is the development of micaceous rock at the contact with the host rock. Mica content in this rock reaches $70-90$ vol.\%. The flake size is 3$5 \mathrm{~mm}$, rarely up to $10 \mathrm{~mm}$. The secondary and accessory minerals are pyroxene, albite, meliphanite, fluorite, nepheline, analcime, britholite and apatite-group minerals, and zircon. Meliphanite forms large (up to $5 \mathrm{~cm}$ ) hypidiomorphic porphyroblastic crystals with numerous mineral inclusions (mainly those of mica). Leucocratic minerals (albite, analcime, nepheline) are aggregated into irregular veins $0.5-2.5 \mathrm{~cm}$ thick. These veins contain minor pyroxene, mica and meliphanite.

\section{Morphology and properties of hainite}

Hainite was found in unhomogeneous aggregates of leucocratic minerals and occur as disseminated individual crystals and aggregate consisting of several dozens of grains. The mineral occur in two morphological types in nearly equal proportion. The morphological type I is represented by 


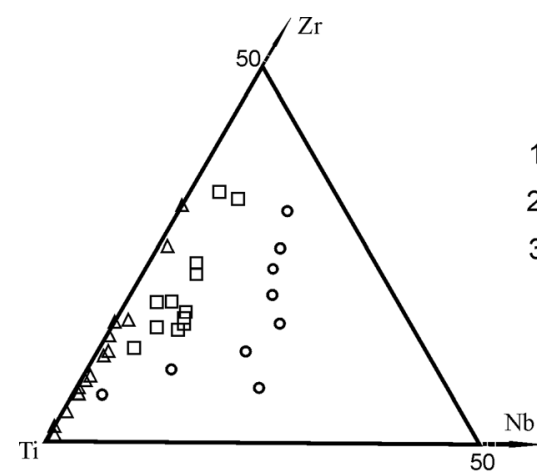

Fig. 3 Chemical composition of the Y-rich hainite from the Sakharjok pegmatite plotted on Ti-Zr-Nb (apfu) and Ca-Na-Y (apfu) diagrams, along with the data on hainite and götzenite for comparative suites (1 hainite from the Sakharjok, 2 - hainite from the others occurrences, 3 -

separate euhedral prismatic (Fig. 1), rarely unhedral crystals and their intergrowths (Fig. 2a). The length of the crystals is up to $2 \mathrm{~mm}$. The morphological type II occurs as rims around an unidentified mineral phase X (Fig. 2b). The grains of the IInd type are similar those of the Ist type and occur as prismatic crystals, intergrowths or euhedral grains. The thickness of hainite rims is $10-100 \mu \mathrm{m}$ (rarely up to $150 \mu \mathrm{m}$ ). The mineral phase $\mathrm{X}$ at the core is of inhomogeneous structure, porous and fractured. The hainite rim is separated from the core phase $\mathrm{X}$ by cracks which are filled by mineral aggregates of different composition. The main chemical components of phase $\mathrm{X}$ are $\mathrm{Si}, \mathrm{Ca}, \mathrm{Y}, \mathrm{Ti}, \mathrm{Zr}$, suggesting that phase $\mathrm{X}$ is close to hainite and could be considered as a $\mathrm{Zr}$-Ti-silicate of $\mathrm{Ca}$ and $\mathrm{Y}$.

In hand specimens, hainite has a milk-white, brownish, or pale pinkish color. It is colorless and transparent in thin chips. The mineral has a perfect cleavage and dim to pearly luster. The mineral fluoresces strongly under the electron beam. Some areas of hainite crystals are porous; the pores are fine (up to several $\mu \mathrm{m}$ ) and have isometric and irregular form (Fig. 2c). The alteration zones of hainite are usually confined to thick fractures in mineral (Fig. 2c). The zones are characterized by the irregular form, more dark shade in the backscattered electron (BSE) images, and numerous parallel oriented thin fractures. From the EMPA data the alteration zones contain less $\mathrm{Ca}$ and $\mathrm{Na}$ than unaltered hainite.

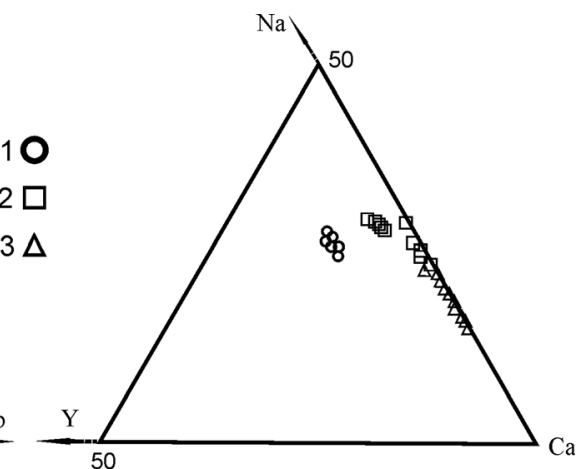

götzenite). Data sources: Bulakh and Kapustin 1973; Christiansen et al. 2003; Bellezza et al. 2004; Cundari and Ferguson 1994; Sharygin et al. 1996; Kapustin 1980; Johan and Čech 1989; Atencio et al. 1999

Hainite from the Sakharjok massif shows internal zoning with variable chemical composition (Fig. 2a). In contrast to hainite from Minas Gerais, the Sakharjok mineral shows no twinning. In rare cases, hainite forms intergrowths with apatite and fluorite, which most probably crystallized simultaneously with hainite. Relations of hainite grains to other minerals indicate its later crystallization relative to pyroxene, nepheline, albite, and the earlier crystallization relative to zeolites.

\section{Mineral composition}

Mineral composition was determined by an electron microprobe at the Geological Institute, Kola Science Centre, Apatity, using a Cameca MS-46 microprobe. The accelerating voltage was $22 \mathrm{kV}$ and the probe current was $30-40 \mathrm{nA}$. Quantitative point analyses were made with a defocused $(10-15 \mu \mathrm{m})$ beam. The following standards were used: wollastonite $(\mathrm{SiK} \alpha, \mathrm{CaK} \alpha)$, hematite $(\mathrm{FeK} \alpha 1)$, lorenzenite $(\mathrm{NaK} \alpha$, TiK $\alpha)$, forsterite $(\mathrm{MgK} \alpha), \mathrm{MnCO} 3(\mathrm{MnK} \alpha 1)$, metallic $\mathrm{Nb}(\mathrm{NbL} \alpha), \mathrm{ZrSiO} 4(\mathrm{ZrL} \alpha), \mathrm{SrSO} 4(\mathrm{SrL} \alpha), \mathrm{Y} 3 \mathrm{Al} 5 \mathrm{O} 12(\mathrm{YL} \alpha$, $\mathrm{AlK} \alpha),(\mathrm{La}, \mathrm{Ce}) \mathrm{S}(\mathrm{LaL} \alpha 1), \mathrm{CeS}(\mathrm{CeL} \alpha 1), \mathrm{LiNd}(\mathrm{MoO} 4) 2$ $(\mathrm{NdL} \alpha 1), \mathrm{GdS}(\mathrm{GdL} \alpha 1), \mathrm{TbPO} 4(\mathrm{TbL} \alpha 1), \mathrm{Dy} 3 \mathrm{~A} 15 \mathrm{O} 12$ (DyL $\alpha 1)$, Ho3Ga5O12 (HoL $\beta 1)$, ErPO4 (ErL $\alpha 1)$, Tm3A15O12 (TmL $\alpha 1), \mathrm{Yb} 3 \mathrm{~A} 15 \mathrm{O} 12(\mathrm{YbL} \alpha 1)$,
Fig. 4 Chondrite-normalised REE patterns. a Hainite (shaded area-Sakharjok; filled squares Bohemia; squares - Minas Gerais; filled circles -

Langesund; circles - Ilímaussaq). b Britholite group minerals from Sakharjok pegmatite (see explanation in the text). Normalising factors from the Sun and McDonough 1989
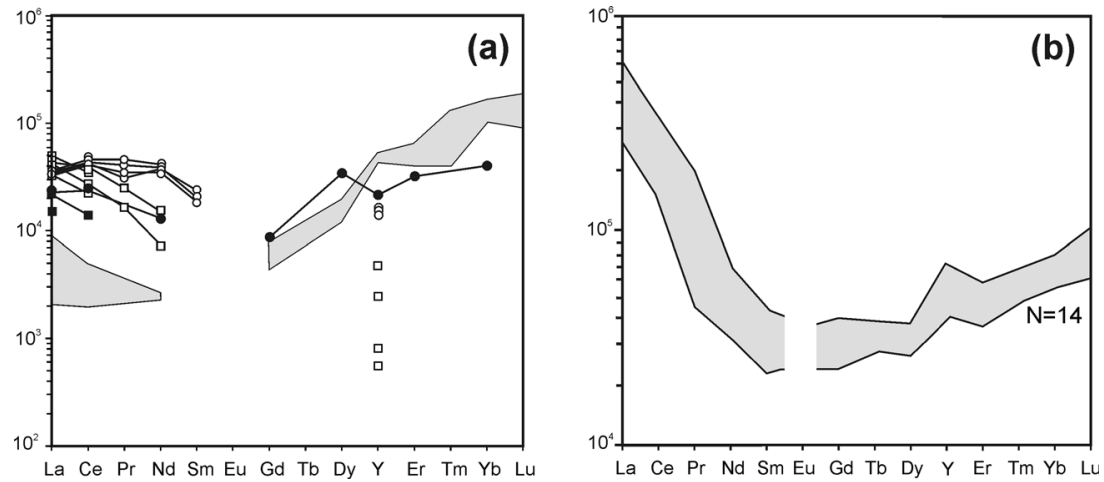
Table 2 Crystal data and structure refinement of Y-rich hainite from the Sakharjok pegmatite (Kola Peninsula, Russia) (sample 4)

\begin{tabular}{ll}
\hline Temperature $(\mathrm{K})$ & $293(2)$ \\
Crystal system & triclinic \\
Space group & $P-1$ \\
$a(\AA)$ & $9.6054(10)$ \\
$b(\AA)$ & $5.6928(6)$ \\
$c(\AA)$ & $7.3344(7)$ \\
$\alpha\left(^{\circ}\right)$ & $89.903(2)$ \\
$\beta\left(^{\circ}\right)$ & $101.082(2)$ \\
$\gamma\left({ }^{\circ}\right)$ & $100.830(2)$ \\
$V\left(\AA^{3}\right)$ & $386.32(7)$ \\
$Z$ & 1 \\
$\rho_{\text {calc }}\left(\mathrm{mg} / \mathrm{mm}^{3}\right)$ & 3.391 \\
$\mu\left(\mathrm{mm}{ }^{-1}\right)$ & 7.328 \\
$F(000)$ & 381.0 \\
Crystal size $(\mathrm{mm})$ & $0.21 \times 0.16 \times 0.10$ \\
$2 \Theta$ range for data collection $\left({ }^{\circ}\right)$ & 4.402 to 74.414 \\
Index ranges & $-16 \leq \mathrm{h} \leq 16,-9 \leq \mathrm{k} \leq 9,-12 \leq 1 \leq 10$ \\
Reflections collected & 15284 \\
Independent reflections & $3991[R(\mathrm{int})=0.0325]$ \\
Data/restraints/parameters & $3991 / 0 / 145$ \\
Goodness-of-fit on $F^{2}$ & 0.939 \\
Final $R$ indexes $[I>=2 \sigma(I)]$ & $R_{1}=0.0333, w R_{2}=0.0810$ \\
Final $R$ indexes [all data $]$ & $R_{1}=0.0486, w R_{2}=0.0905$ \\
Largest diff. peak/hole $\left(\mathrm{e} \AA^{-3}\right)$ & $2.35 /-1.20$ \\
\hline
\end{tabular}

Y2.8Lu0.2Al5O12 (LuL $\alpha 1)$, UO2 (UM $\alpha)$. Fluorine content was determined using LEO-1450 SEM equipped with an XFlash-5010 Bruker Nano GmbH EDS. The electron microscope operated at acceleration voltage $20 \mathrm{kV}$, current intensity $0.5 \mathrm{nA}$, accumulation time $200 \mathrm{~s}$, procedure of standard-free analysis by the P/B-ZAF method of the QUANTAX system.

Representative analyses are given in Table 1. Hainite formulae have been calculated on the basis of $4 \mathrm{Si}$ in accord with the halved general formula for the rosenbuschite group $(\mathrm{M} 1)_{4}(\mathrm{M} 2)_{4}(\mathrm{M} 3)_{4}(\mathrm{M} 4)_{2}(\mathrm{M} 5)_{2}\left(\mathrm{Si}_{2} \mathrm{O}_{7}\right)_{4} \mathrm{~F}_{4} \mathrm{X}_{4}$ and following the scheme simplified formula for the hainite $(\mathrm{Ca}, \mathrm{Zr}, \mathrm{Y})_{2}(\mathrm{Na}$, $\mathrm{Ca})_{2} \mathrm{Ca}_{2} \mathrm{NaTi}\left(\mathrm{Si}_{2} \mathrm{O}_{7}\right)_{2} \mathrm{~F}_{2} \mathrm{~F}_{2}$ (Christiansen et al. 2003).

All analyzed samples show cation deficiency (sum of cations is 7.30-7.90 against theoretical 8). The above mentioned internal zoning is manifested in the distinct chemical composition (samples 2 and 3 (Table 1) were analyzed in different zones of the same crystal and differ mainly in $\mathrm{Nb}, \mathrm{Zr}$ and $\mathrm{Ti}$ contents). Most significant variations in the analyzed samples have been found for $\mathrm{Zr}$ (threefold times) and $\mathrm{Nb}$ (fivefold times). The Sakharjok hainite is rich in Y and REE (average values 0.65 and $0.22 a p f u$, correspondingly (Table 1)), which is significantly higher than that observed for hainite from Ilímaussaq, Langesund, and Minas Gerais.

The comparison of the hainite compositions from Sakharjok and other localities along with the composition of götzenite revealed the follow regularities. Hainite differs from götzenite in the higher $\mathrm{Zr}$ and $\mathrm{Na}$ contents (Fig. 3). At the same time, Sakharjok hainite is characterized by the elevated $\mathrm{Y}$ and $\mathrm{Nb}$ contents compared to the finds from other localities. This can be explained by a high activity of $\mathrm{Y}$ and $\mathrm{Nb}$ in the Sakharjok nepheline syenite magma and postmagmatic products.

The chondrite-normalized REE pattern for the Sakharjok hainite (Fig. 4) is strongly unfractionated (the average $\mathrm{Ce} / \mathrm{Y}_{\mathrm{n}}$ value is 0.07 ). It should be noted that, in contrast to Sakharjok,
Table 3 Atomic coordinates, occupancies and equivalent isotropic displacement parameters $\mathrm{U}_{\text {eq }}\left(\AA^{2} \times 10^{3}\right)$ in Y-rich hainite from the Sakharjok pegmatite (Kola Peninsula, Russia) (sample 4)

\begin{tabular}{|c|c|c|c|c|c|}
\hline Atom & $x$ & $y$ & $z$ & occupancy & $\mathrm{U}($ eq. $)$ \\
\hline M1 & $0.63494(3)$ & $0.22243(4)$ & $0.91042(3)$ & $\mathrm{Ca}_{0.53} \mathrm{Y}_{0.33} \mathrm{REE}_{0.13} \mathrm{Mn}_{0.01}$ & $10.43(7)$ \\
\hline M2 & $0.99577(9)$ & $0.4973(1)$ & $0.2446(1)$ & $\mathrm{Na}_{0.61} \mathrm{Ca}_{0.39}$ & $21.0(3)$ \\
\hline M3 & $0.63580(5)$ & $0.22290(8)$ & $0.40921(6)$ & $\mathrm{Ca}$ & $16.77(13)$ \\
\hline M4 & 0 & 0 & 0.5 & $\mathrm{Na}_{0.87} \mathrm{Ca}_{0.13}$ & $21.7(5)$ \\
\hline M5 & 0 & 0 & 0 & $\mathrm{Ti}_{0.60} \mathrm{Zr}_{0.23} \mathrm{Nb}_{0.14} \mathrm{Fe}_{0.03}$ & $19.78(14)$ \\
\hline Sil & $0.71371(6)$ & $0.7469(1)$ & $0.65096(8)$ & $\mathrm{Si}$ & $10.23(12)$ \\
\hline $\mathrm{Si} 2$ & $0.72028(6)$ & $0.7486(1)$ & $0.21358(8)$ & $\mathrm{Si}$ & $10.31(12)$ \\
\hline $\mathrm{O} 1$ & $0.7495(2)$ & $0.7793(4)$ & $0.4408(3)$ & $\mathrm{O}$ & $29.1(5)$ \\
\hline $\mathrm{O} 2$ & $0.6142(2)$ & $0.9412(3)$ & $0.6717(3)$ & $\mathrm{O}$ & $16.3(3)$ \\
\hline $\mathrm{O} 3$ & $0.6155(2)$ & $0.9326(3)$ & $0.1368(3)$ & $\mathrm{O}$ & $18.7(3)$ \\
\hline $\mathrm{O} 4$ & $0.6390(2)$ & $0.4735(3)$ & $0.6693(3)$ & $\mathrm{O}$ & $23.0(4)$ \\
\hline O5 & $0.6567(3)$ & $0.4734(3)$ & $0.1553(3)$ & $\mathrm{O}$ & $25.7(4)$ \\
\hline O6 & $0.8743(2)$ & $0.8111(4)$ & $0.7818(3)$ & $\mathrm{O}$ & 21.9(4) \\
\hline $\mathrm{O} 7$ & $0.8826(2)$ & $0.8290(4)$ & $0.1718(3)$ & $\mathrm{O}$ & $20.9(4)$ \\
\hline $\mathrm{X} 8$ & $0.8813(2)$ & $0.2583(3)$ & $0.9671(2)$ & $\mathrm{F}_{0.53} \mathrm{O}_{0.47}$ & $20.7(4)$ \\
\hline F9 & $0.8820(2)$ & $0.3019(3)$ & $0.4739(3)$ & F & $28.0(4)$ \\
\hline
\end{tabular}


Table 4 Bond lengths $(\AA)$ in Y-rich hainite from the Sakharjok pegmatite (Kola Peninsula, Russia) (sample 4)

\begin{tabular}{llllll}
\hline M1-O2 & $2.329(2)$ & M3-O1 & $2.926(3)$ & M5-O6 & $1.988(2)$ \\
M1-O3 & $2.347(2)$ & M3-O2 & $2.366(2)$ & M5-O6 & $1.988(2)$ \\
M1-O3 & $2.359(2)$ & M3-O2 & $2.518(2)$ & M5-O7 & $1.984(2)$ \\
M1-O4 & $2.273(2)$ & M3-O3 & $2.550(2)$ & M5-O7 & $1.984(2)$ \\
M1-O5 & $2.250(2)$ & M3-O4 & $2.376(2)$ & M5-X8 & $2.011(2)$ \\
M1-X8 & $2.292(2)$ & M3-O5 & $2.360(2)$ & M5-X8 & $2.011(2)$ \\
$<$ M1-O> & 2.308 & M3-F9 & $2.278(2)$ & $<$ M5-O $>$ & 1.994 \\
& & $<$ M3-O,F> & 2.482 & & \\
M2-O6 & $2.366(2)$ & & & Si1-O1 & $1.645(2)$ \\
M2-O7 & $2.361(2)$ & M4-O1 & $2.454(2)$ & Si1-O2 & $1.617(2)$ \\
M2-X8 & $2.412(2)$ & M4-O1 & $2.454(2)$ & Si1-O4 & $1.604(2)$ \\
M2-X8 & $2.406(2)$ & M4-O6 & $2.712(2)$ & Si1-O6 & $1.629(2)$ \\
M2-F9 & $2.346(2)$ & M4-O6 & $2.712(2)$ & $<$ Si1-O $>$ & 1.624 \\
M2-F9 & $2.350(2)$ & M4-O7 & $2.562(2)$ & & \\
$<$ M2-O,F> & 2.374 & M4-O7 & $2.562(2)$ & Si2-O1 & $1.640(2)$ \\
& & M4-F9 & $2.219(2)$ & Si2-O3 & $1.614(2)$ \\
& & M4-F9 & $2.219(2)$ & Si2-O5 & $1.598(2)$ \\
& & $<$ M4-O,F> 2.478 & Si2-O7 & $1.628(2)$ \\
& & & & $<$ Si2-O $>$ & 1.620 \\
\hline & & & &
\end{tabular}

fractionated patterns of REE have been observed for hainite from others localities. The $\mathrm{Ce} / \mathrm{Y}_{\mathrm{n}}$ value ranges from 7 to 49 for Minas Gerais, 2.6 to 2.8 for Ilímaussaq, and 1.1 for Langesund. The Sakharjok hainite differs from all the previously studied samples in the two- to fivefold depletion by the light REEs (in some samples $\mathrm{La}$ and $\mathrm{Ce}$ contents are below the detection limits (Table 1)). The observed peculiarities of the $R E E$ distribution in hainite may be explained by the HREE-Y enrichment of parental melts/fluid for the Sakharjok pegmatite. Another possible explanation is the genetic relationship of the Langesund, Ilímaussaq and Sakharjok hainites with the nepheline syenite pegmatites, while other hainite occurrences are confined to volcanic rocks only.

Britholite group minerals are the other main carriers of REE in studied pegmatite (Lyalina et al. 2014; Zozulya et al. 2014). Comparing to hainite they are enriched in light REEs (the average $\mathrm{Ce} / \mathrm{Y}_{\mathrm{n}}$ value is 3.5) (Fig. 4), indicating the different geochemical conditions of hainite and britholites crystallization. The chondrite-normalized REE pattern for britholites shows the $\mathrm{Y}$ positive anomaly that is in response to yttrium specialization of parental nepheline syenite magma (Zozulya et al. 2012).

\section{Crystal structure}

\section{Experimental}

The crystal of sample 4 (Table 1) selected for the X-ray diffraction experiment was mounted on a Bruker DUO CCD diffractometer operated at $45 \mathrm{kV}$ and $0.65 \mathrm{~mA}$. Data were collected using monochromatic $\operatorname{MoK} \alpha \mathrm{X}$-radiation (Table 2). The intensity data were reduced and corrected for Lorentz, polarization, and background effects using the Bruker software. A semi-empirical absorption-correction based upon the intensities of equivalent reflections was applied. The structure was solved with the ShelXS (Sheldrick 2008) structure solution program using Direct Methods and refined with the ShelXL (Sheldrick 2008) refinement package using Least Squares minimization. The basic refinement parameters are given in Table 2. The final coordinates and
Table 5 Anisotropic Displacement Parameters $\left(\AA^{2} \times\right.$ $10^{3}$ ) for Y-rich hainite from the Sakharjok pegmatite (Kola Peninsula, Russia) (sample 4)

\begin{tabular}{llccccc}
\hline Atom & $\mathrm{U}_{11}$ & $\mathrm{U}_{22}$ & $\mathrm{U}_{33}$ & $\mathrm{U}_{23}$ & $\mathrm{U}_{13}$ & $\mathrm{U}_{12}$ \\
\hline M1 & $12.73(11)$ & $10.25(10)$ & $7.17(10)$ & $-0.23(7)$ & $2.22(7)$ & $-0.92(7)$ \\
M2 & $31.0(5)$ & $16.9(4)$ & $17.4(4)$ & $1.4(2)$ & $6.6(3)$ & $8.6(3)$ \\
M3 & $15.0(2)$ & $21.5(2)$ & $11.04(19)$ & $-1.17(14)$ & $3.28(14)$ & $-4.28(15)$ \\
M4 & $12.5(7)$ & $26.1(8)$ & $25.3(8)$ & $-2.0(5)$ & $0.0(5)$ & $4.3(5)$ \\
M5 & $18.9(2)$ & $26.3(2)$ & $8.96(18)$ & $-1.88(14)$ & $3.56(14)$ & $-9.54(15)$ \\
Si1 & $10.8(2)$ & $10.9(2)$ & $9.2(2)$ & $0.12(17)$ & $1.91(18)$ & $2.66(18)$ \\
Si2 & $11.0(2)$ & $11.0(2)$ & $9.6(2)$ & $1.09(17)$ & $2.52(18)$ & $3.24(18)$ \\
O1 & $27.9(10)$ & $48.5(13)$ & $9.3(7)$ & $0.1(8)$ & $6.1(7)$ & $0.8(9)$ \\
O2 & $13.4(7)$ & $14.0(7)$ & $22.0(8)$ & $-3.2(6)$ & $2.3(6)$ & $4.9(5)$ \\
O3 & $16.6(7)$ & $18.4(8)$ & $22.4(8)$ & $5.2(6)$ & $2.2(6)$ & $8.5(6)$ \\
O4 & $32.9(10)$ & $13.5(7)$ & $21.8(8)$ & $1.2(6)$ & $7.6(7)$ & $-0.3(7)$ \\
O5 & $40.7(12)$ & $13.3(8)$ & $21.5(9)$ & $-2.6(6)$ & $8.7(8)$ & $-2.0(7)$ \\
O6 & $16.6(8)$ & $25.4(9)$ & $21.0(8)$ & $-5.3(7)$ & $-4.9(6)$ & $6.5(7)$ \\
O7 & $14.2(7)$ & $26.8(9)$ & $24.4(9)$ & $7.3(7)$ & $9.2(6)$ & $5.1(6)$ \\
X8 & $15.5(7)$ & $24.7(9)$ & $21.6(8)$ & $0.7(6)$ & $2.4(6)$ & $4.0(6)$ \\
F9 & $19.4(7)$ & $25.0(8)$ & $38.7(10)$ & $1.2(7)$ & $3.4(7)$ & $4.5(6)$ \\
\hline
\end{tabular}


Table 6 Site occupancy, coordination number $(\mathrm{CN})$ and average bond lengths (ABL, $\AA$ ) of Y-rich hainite from the Sakharjok pegmatite (Kola Peninsula, Russia) (sample 4) in comparison with those in hainite and götzenite (Christiansen et al. 2003)

\begin{tabular}{clll}
\hline Site & $\mathrm{Occupancy}$ & $\mathrm{CN}$ & $\mathrm{ABL}$ \\
\hline Sample 4 & & & \\
M1 & $\mathrm{Ca}_{0.53} \mathrm{Y}_{0.33} \mathrm{REE}_{0.13} \mathrm{Mn}_{0.01}$ & 6 & 2.308 \\
M2 & $\mathrm{Na}_{0.61} \mathrm{Ca}_{0.39}$ & 6 & 2.374 \\
M3 & $\mathrm{Ca}$ & 6 & 2.408 \\
& & 7 & 2.482 \\
M4 & $\mathrm{Na}_{0.87} \mathrm{Ca}_{0.13}$ & 8 & 2.478 \\
M5 & $\mathrm{Ti}_{0.60} \mathrm{Zr}_{0.23} \mathrm{Nb}_{0.14} \mathrm{Fe}_{0.03}$ & 6 & 1.994 \\
hainite & & & \\
M1 & $\mathrm{Ca}_{0.60} \mathrm{Y}_{0.16} \mathrm{REE}_{0.10} \mathrm{Zr}_{0.1} \mathrm{Mn}_{0.04}$ & 6 & 2.312 \\
M2 & $\mathrm{Na}_{0.51} \mathrm{Ca}_{0.49}$ & 6 & 2.374 \\
M3 & $\mathrm{Ca}_{0.97} \mathrm{REE}_{0.03}$ & 6 & 2.417 \\
& & 7 & 2.498 \\
M4 & $\mathrm{Na}_{0.83} \mathrm{Ca}_{0.17}$ & 8 & 2.482 \\
M5 & $\mathrm{Ti}_{0.78} \mathrm{Nb}_{0.08} \mathrm{Fe}_{0.08} \mathrm{Zr}_{0.06}$ & 6 & 1.986 \\
götzenite & & & \\
M1 & $\mathrm{Ca}_{0.81} \mathrm{REE}_{0.06} \mathrm{Mn}_{0.06} \mathrm{Zr}_{0.04} \mathrm{Y}_{0.03}$ & 6 & 2.344 \\
M2 & $\mathrm{Ca}_{0.61} \mathrm{Na}_{0.39}$ & 6 & 2.370 \\
M3 & $\mathrm{Ca}_{0.94} \mathrm{REE}_{0.06}$ & 6 & 2.412 \\
& & 7 & 2.494 \\
M4 & $\mathrm{Na}_{0.81} \mathrm{Ca}_{0.19}$ & 8 & 2.470 \\
M5 & $\mathrm{Ti}_{0.92} \mathrm{Fe}_{0.05} \mathrm{Nb}_{0.03}$ & 6 & 1.972 \\
\hline
\end{tabular}

isotropic displacement parameters are listed in Table 3, selected interatomic distances are in Table 4 and anisotropic displacement parameters are in Table 5.

\section{Structure description}

The crystal structure of sample 4 is similar to the structures of hainite and götzenite (Atencio et al. 1999; Bulakh and Kapustin 1973; Cannillo et al. 1972; Johan and Čech 1989; Sokolova 2006; Sokolova and Camara 2013; Rastsvetaeva et al. 1995), which belong to the rosenbuschite mineral group (Christiansen et al. 2003). The crystal structure consists of $\mathrm{HOH}$ layers (Fig. 5), where $H$ is a heteropolyhedral sheet composed of cations in the octahedral $\mathrm{M}^{1}$ and $\mathrm{M} 3$ positions linked to $\mathrm{Si}_{2} \mathrm{O}_{7}$ tetrahedral groups. The $O$-sheet consists of the octahedra centered by the M2, M4, and M5 cations. Cation distribution over the M1, M2, M3, M4, and M5 sites was discussed in details by Christiansen et al. (2003). Here we discuss only the differences of the structure of our mineral with those of hainite and götzenite. Distribution of cations over inequivalent positions is given in Table 6 in comparison with those in hainite and götzenite. Compared to hainite, there is a significant

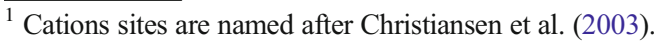

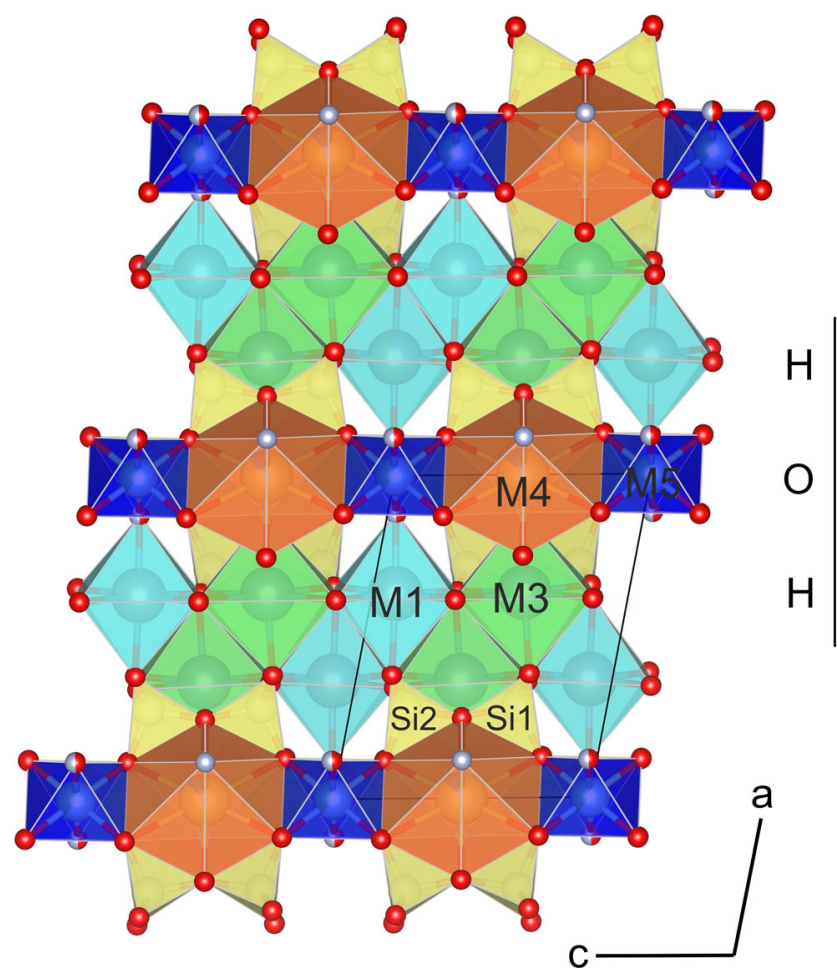

Fig. 5 Crystal structure of the Y-rich hainite from the Sakharjok pegmatite, Kola Peninsula. Projection along the axis $b$

amount of $\mathrm{Y}$ in the M1 site and corresponding Ca decrease and the absence of $\mathrm{Zr}$, which is a key feature of our sample. The M3 site has coordination number $(\mathrm{CN})$ equal to 6 or 7 and is fully occupied by $\mathrm{Ca}$. The average $<\mathrm{M} 1-\mathrm{O}>$ bond length is $2.308 \AA$, whereas individual M1-O bond lengths vary in the range of 2.250-2.359 $\AA$. The average $<\mathrm{M} 3-\mathrm{O} / \mathrm{F}>$ bond length is $2.482 \AA(\mathrm{CN}=7)$ with the variation range from 2.278 to $2.926 \AA$. The M2, M4, M5 cation positions form the O layer. In the case of our structure, the layer can be considered as consisting of two columns extending along the $c$ axis

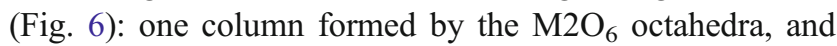

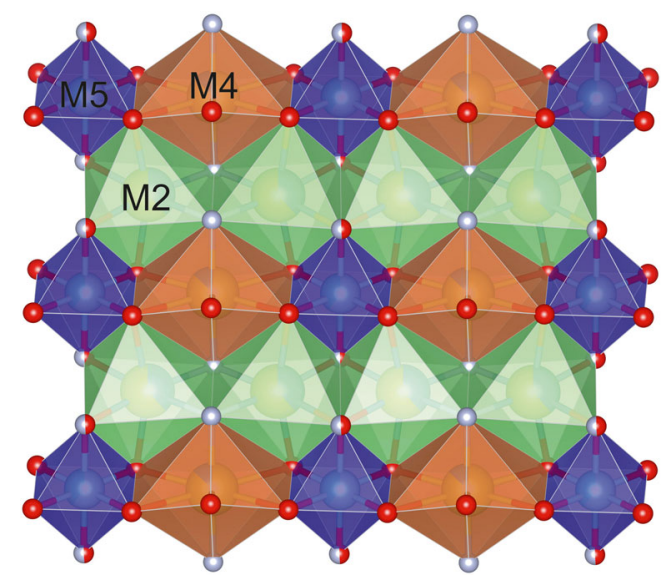

Fig. 6 M2, M4, M5 cation sites. Two columns extending along the $c$ axis: one column of M2 octahedra, the second of alternating polyhedra M4 and M5 
the second formed by alternating M4 and M5 octahedra. The M2 site is occupied by $\mathrm{Na}$ and $\mathrm{Ca}$ in the 0.60:0.40 ratio, with the average $<\mathrm{M} 2-\mathrm{O}>$ bond length of $2.374 \AA$. The $\mathrm{M} 4$ position $(\mathrm{CN}=8)$ is mainly occupied by Na with the average $<\mathrm{M} 4-\mathrm{O}>$ bond length of $2.478 \AA$. It is noteworthy that all $\mathrm{Zr}$ is in the M5 site that is different from the data reported by Christiansen et al. (2003). Thus, $\mathrm{Ti}, \mathrm{Zr}, \mathrm{Nb}$ are concentrated in the M5 site with the average $<$ M5-O $>$ bond length of $1.994 \AA$. There is no ordering of $\mathrm{Na}$ and $\mathrm{Ca}$ in the octahedral layer, which is in agreement with the observations by Christiansen et al. (2003). This suggests that the triclinic structure of hainite is centrosymmetric. We note, however, that Rastsvetaeva et al. (1995) and Atencio et al. (1999) described hainite with completely ordered $\mathrm{Ca}$ - and Na-atoms in two crystallographically independent sites (space group $P 1$ ).

The comparison of the hainite composition derived from the site occupancies (Table 6) with that obtained from the microprobe data (Table 1) shows good agreement for most elements.

Similarly to hainite, the structure of sample 4 contains separate $\mathrm{F}$ site with the $\mathrm{F}: \mathrm{O}$ ratio close to $1: 1$. Thus, the sample studied is the Y-rich variety of hainite with the amount of Y approximately 2 times higher than that in hainite. The crystal chemical formula of sample 4 can be written as $\left(\mathrm{Ca}_{1.04} \mathrm{Y}_{0.63} \mathrm{REE}_{0.24} \mathrm{Mn}_{0.02}\right)_{\sum 1.93}\left(\mathrm{Na}_{0.92} \mathrm{Ca}_{0.77}\right)_{\sum 1.69} \mathrm{Ca}_{2.00}$ $\left(\mathrm{Na}_{0.65} \mathrm{Ca}_{0.10}\right)_{\sum 0.75}\left(\mathrm{Ti}_{0.60} \mathrm{Zr}_{0.21} \mathrm{Nb}_{0.15} \mathrm{Fe}_{0.03}\right)_{\sum 0.99}$ $\left(\left(\mathrm{Si}_{4.00} \mathrm{Al}_{0.02}\right)_{\sum 4.02} \mathrm{O}_{14}\right)\left(\mathrm{F}_{2.61} \mathrm{O}_{1.39}\right)_{\sum 4.00}$ (based on $\mathrm{Si}=4$ apfu).

\section{X-ray powder diffraction}

The X-ray powder diffraction pattern of the sample 4 was obtained using a Rigaku R-AXIS RAPID II diffractometer system (Gandolfi-like mode, $\mathrm{CoK} \alpha$ radiation) and is very close to those reported by Atencio et al. (1999) and Rønsbo et al. (2014). The unit-cell parameters determined from the powder-diffraction data using UnitCell program are as follows: $a=9.598(6), b=5.695(3), c=7.343(4) \AA, \alpha=89.91(5)$, $\beta=100.95(5), \gamma=100.85(6)^{\circ}, \mathrm{V}=386.8(2) \AA^{3}$ that are in good agreement with the single-crystal data (see Table 2).

\section{Conclusions}

In conclusion, hainite is first described in alkaline rocks of the Sakharjok massif (Kola Peninsula, Russia). The mineral is found in a nepheline syenite pegmatite. Hainite crystallized at late stage of pegmatite formation. Hainite exhibits two morphological types: (1) separate prismatic crystals, and (2) rims around an unidentified mineral phase, possibly Zr-Ti-silicate of calcium and yttrium.

The chemical composition of Sakharjok hainite varies both within the single crystal (internal zoning) and between different grains. Most significant variations in the analyzed samples are found for $\mathrm{Zr}$ and $\mathrm{Nb}$. Mineral from Sakharjok differs significantly from the previously described occurrences by the strong enrichment in $\mathrm{Y}$ and $\mathrm{Nb}$. It is suggested that this feature is due to a high $\mathrm{Y}$ and $\mathrm{Nb}$ activity in crystallization media.

It is established that in hainite studied $\mathrm{Y}$ and $R E E$ substitute $\mathrm{Ca}$ in the $\mathrm{M} 1$ site, $\mathrm{Nb}$ and $\mathrm{Zr}$ substitute $\mathrm{Ti}$ in the M5 site. Further increases of yttrium content may lead to Y predominance in the M1 site with formation of new mineral species respectively. Charge balance at substitution of divalent calcium by trivalent yttrium can be achieved in various ways, for example: 1) $\mathrm{Ca}^{2+} \leftrightarrow \mathrm{Y}^{3+}$ (at the M1 site) and $\mathrm{Ca}^{2+} \leftrightarrow \mathrm{Na}^{+}$(at the M2 and/or M3 sites); 2) $3 \mathrm{Ca}^{2+} \leftrightarrow 2 \mathrm{Y}^{3+}+\square$, where the $\mathrm{Y}^{3+} \rightarrow \mathrm{Ca}^{2+}$ substitution occurs at the M1 site and the M2 and/or M4 become predominantly vacant. The last substitution scheme is likely as all analyzed samples show cation deficiency.

The Sakharjok hainite is centrosymmetric, i.e., does not possess any $\mathrm{Ca}-\mathrm{Na}$ ordering in the octahedral layer.

Acknowledgments We thank the referees F. Camara and N. Chukanov for their helpful comments about the manuscript. The study was supported by grant from St. Petersburg State University (No 3.38.136.2014). A. Zolotarev is grateful to President Federation Grant for Young Candidates of Sciences (MK-3296.2015.5).

\section{References}

Atencio D, Coutinho JMV, Ulbrich MNC, Vlach SRF, Rastsvetaeva RK, Pushcharovsky DY (1999) Hainite from Poços de Caldas, Minas Gerais, Brazil. Can Mineral 37:91-98

Batieva ID, Bel'kov IV (1984) The Saharjok alkaline intrusion: rocks and minerals. Kola Branch, USSR. Acad. Sci., Apatity, 133 pp [in Russian]

Bellezza M, Merlino S, Perchiazzi N (2004) Chemical and structural study of the $\mathrm{Zr}$, Ti-disilicates in the venanzite from Pian di Celle, Umbria, Italy. Eur J Mineral 16:957-969

Blumrich J (1893) Die phonolithe des Friedländer Bezirkes in Nordböhmen. Tschermaks Mineral Petrogr Mitt 13:465-495

Bulakh AG, Kapustin YL (1973) Götzenite from alkaline rocks of Turii Peninsula (Kola Peninsula). Zap Vses Mineral O-va 102:464-466, [in Russian]

Cannillo E, Mazzi F, Rossi G (1972) Crystal structure of götzenite. Soviet Physics, Crystallog 16:1026-1030

Christiansen CC, Johnsen O, Makovicky E (2003) Crystal chemistry of the rosenbuschite group. Can Mineral 41:1203-1224

Cundari A, Ferguson AJ (1994) Appraisal of the new occurrence of götzenite $_{S S}$, khibinskite and apophyllite in kalsilite-bearing lavas from San Venanzo and Cupaello (Umbria), Italy. Lithos 31:155-161

Giester G, Pertlik F, Ulrych J (2005) Die Kristallstruktur des Minerals Hainit. Mitt Österr Mineral Ges 151:45, [in German]

Guimarães D (1948) The zirconium ore deposits of the Pogos de Caldas plateau, Brazil, and zirconium geochemistry. Instituto de Tecnologia Industrial, Boletim 6

Johan Z, Čech F (1989) New data on hainite, $\mathrm{Na}_{2} \mathrm{Ca}_{4}[(\mathrm{Ti}, \mathrm{Zr}, \mathrm{Mn}, \mathrm{Fe}, \mathrm{Nb}$, $\left.\mathrm{Ta})_{1.50} \square_{0.50}\right]\left(\mathrm{Si}_{2} \mathrm{O}_{7}\right) \mathrm{F}_{4}$ and its crystallochemical relationship with götzenite, $\mathrm{Na}_{2} \mathrm{Ca}_{5} \mathrm{Ti}\left(\mathrm{Si}_{2} \mathrm{O}_{7}\right)_{2} \mathrm{~F}_{4}$. C.R. Acad. Sci. Paris 308, series II: 1237-1242 [in French, with extended English abstract] 
Kapustin YL (1980) Götzenite and wöhlerite from alkaline massif of Sangilen (Tuva). Zap Vses Mineral O-va 109:594-599, [in Russian]

Lyalina LM, Savchenko YE, Selivanova EA, Zozulya DR (2010) Behoite and mimetite from the Saharjok alkaline pluton, Kola Peninsula. Geology of Ore Deposits 52:641-645

Lyalina LM, Zozulya DR, Savchenko YeE (2014) Diversity of britholite group minerals in nepheline-feldspar pegmatite from Sakharjok massif, Kola Peninsula. Geologiya i strategicheskie poleznyie iskopaemyie Kolskogo regiona. Trudy XI Vserossiyskaya Fersmanovskaya nauchnaya sessiya:97-101 [in Russian]

Rastsvetaeva RK, Pushcharovskii DY, Atencio D (1995) Crystal structure of giannetite. Crystallography Reports 40:574-578

Rønsbo JG, Sørensen H, Roda-Robles E, Fontan F, Monchoux P (2014) Rinkite-nacareniobsite-(Ce) solid solution series and hainite from the Ilímaussaq alkaline complex: occurrence and compositional variation. Bull Geol Soc Den 62:1-15

Sharygin VV, Stoppa F, Kolesov BA (1996) Zr-Ti disilicates from the Pian di Celle volcano, Umbria, Italy. Eur J Mineral 8:1199-1212

Sheldrick GM (2008) SHELXS, SHELXL. Acta Crystallogr A64:112122
Sokolova E (2006) From structure topology to chemical composition. I. Structural hierarchy and stereochemistry in titanium disilicate minerals. Can Mineral 44:1273-1330

Sokolova E, Cámara F (2013) From structure topology to chemical composition. XVI. New developments in the crystal chemistry and prediction of new structure topologies for titanium disilicate minerals with the TS block. Can Mineral 51:861-891

Sun SS, McDonough WF (1989) Chemical and isotopic systematics of oceanic basalts: applications for mantle composition and processes. In: Saunders AD, Norry MJ (eds) Magmatism in the ocean basins, special publication of the geological society 42 . Geological Society, London, pp 313-345

Zozulya DR, Lyalina LM, Eby N, Savchenko YE (2012) Ore geochemistry, zircon mineralogy, and genesis of the Sakharjok Y-Zr deposit, Kola Peninsula, Russia. Geology of Ore Deposits 54:81-98

Zozulya D, Lyalina L, Macdonald R, Bagiński B, Savchenko Ye, Dzierżanowski P (2014) Genesis and alteration mechanisms of britholite group minerals from ore bodies related to the Keivy peralkaline granite-nepheline syenite complex, Kola Peninsula, NW Russia. Workshop on accessory minerals, University of Warsaw:43-44 